PAPERS READ.

\title{
DESCRIPTION OF A NEW SPECIES OF IODIS, WITH REMARKS ON PIELUS IMPERIALIS, OLLIFF.
}

\section{By Thomas P. Lucas, M.R.C.S., L.S.A., Lond., L.R.C.P., Edrn.}

The past season in Brisbane has been most unfavourable for the appearance of Lepidoptera. Many of the new species of Iodis I found last year have not turned up at all, and all have been rare. I have found $I$. leucomerata here for the first time. I obtained one worn specimen of a new species early in the year, but must wait for describing until I obtain better specimens. But last April Mr. Illidge was fortunate enough to discover a novel and most interesting species on a small tree growing in his garden, which he had transplanted from the bush. With a lantern light he discovered the imago flying rapidly around the tree, and afterwards Mrs. Illidge found the pupa cases in very light cocoons among the leaves, evidently showing that the larvæ had fed there, and that the moths were there to deposit their eggs. I have great pleasure in naming the species after its discoverer.

\section{IODIS IlLIDGEI, sp.nov.}

ธิㅇ. 25-30 mm. Face brown-red, fillet yellow-green, crown green with a very fine white line posteriorly. Palpi greenish-white. Antennæ yellow-green, pectinations of $\hat{\sigma}$ short, white-green. Thorax pea-green, dorsum posteriorly yellow-green, undersurface white. Abdomen pea-green, dorsum yellow-green, lateral surface posteriorly and undersurface white. Legs white, upper surface of anterior coxæ and tibiæ brownish-white. Forewings, costa nearly straight, rounded towards apex, hindmargin obliquely rounded, pea-green; costal line and hindmarginal line yellow-green: cilia 
greenish - white. Hindwings as forewings, hindmarginal line yellow-green; hindmargin slightly angled at vein 4: cilia greenish-white. Undersurface of wings greenish-white.

The light pea-green colour, absence of markings, and the yellow-green borders of wings readily distinguish this species. It comes near to Urolitha bipunctifera, Walk., but appears to be a true Iodis.

Postscript.-Since writing the above, I find that the tree on which these caterpillars feed is Duboisia myoporoides. Dr. Thomas L. Bancroft found the exuvia of a caterpillar, probably a larger species, among a quantity of collected leaves. It contaired the active poison principle duboisin. Caterpillar elongated, flattened, green with lighter green and darker green linear stripes laterally.

In the Proceedings of this Society for 1887, (p. 1016, pl. xxxix.), Mr. Olliff described and figured a moth of the genus Pielus belonging to Mr. Prince. I happened to be present at the meeting at which the specimen was exhibited, and stated that I possessed three specimens from the Gippsland District. I had sent an example to Mr. Meyrick, who afterwards returned it named $P$. hyalinatus. On referring to Schäffer's Lepidopt. Exot. Nov. Ser. i, fig. 50, I find an almost exact coloured copy of Pl. xxxix. of P.L.S. N.S.W., and the insect named $P$.hyalinatus. Walker also described it nnder the name $P$. hyalinatus, and referred to Schäffer; hence Mr. Olliff's name $P$. imperialis must give way to $P$. hyalinatus.

I have a specimen I take to be the $\hat{\sigma}$. It is $75 \mathrm{~mm}$., and is marked similarly to the larger ones, but the two apical spots alone of the oblique row of spots parallel with the hindmargin of the forewings are silvered. 


\section{$2 \mathrm{BHL}$ Biodiversity Heritage Library}

Lucas, Thomas Pennington. 1890. "Description of a new species of Iodis, with remarks on Pielus imperialis, Olliff." Proceedings of the Linnean Society of New South Wales 4, 603-604. https://doi.org/10.5962/bhl.part.15055.

View This Item Online: https://www.biodiversitylibrary.org/item/29780

DOI: https://doi.org/10.5962/bhl.part.15055

Permalink: https://www.biodiversitylibrary.org/partpdf/15055

\section{Holding Institution}

MBLWHOI Library

\section{Sponsored by}

MBLWHOI Library

\section{Copyright \& Reuse}

Copyright Status: NOT_IN_COPYRIGHT

This document was created from content at the Biodiversity Heritage Library, the world's largest open access digital library for biodiversity literature and archives. Visit BHL at https://www.biodiversitylibrary.org. 